\title{
Transformational Leadership and Mohtarma Benazir Bhutto
}

\author{
Naheed Malbari \\ Dr. Javaid Laghari
}

\begin{abstract}
Theories of leadership, over decades have explored a wide variety of concepts. Much research has been undertaken keeping in mind the western society both relating to organizations as well as political and other leaders. There is a dearth of a systematic leadership study in regards to either organizations or political leadership in third world countries, especially in Pakistan. Journalistic appraisals are commonly done but theoretical analysis is sorely missing. Also, not much work has been done to explore the concept of transformational leadership among politicians both here and abroad. This paper aims to bridge he prevailing gap. When reading about Bhutto's life, the easiest course of action would have been to view her from the perspective of traits or simply charisma. The paper explores the contemporary concept of transformational leadership in the context of Benazir Bhutto. Her assassination formed the motivational factor to conduct such a research, particularly on a personality known nationally and internationally as a leader. In addition, quantitative small scale researches are usually conducted from time to time, but very little attention is given to qualitative/descriptive/documentary research. Such forms of methodological pluralism are not part of the research strategy approved by many. However, to understand and view Bhutto from the point of view of contemporary thought in leadership makes the task much more interesting.
\end{abstract}

Keywords: Transformational leadership, idealized influence, inspirational motivation, intellectual stimulation, individualized consideration.

\section{Introduction}

'Leadership is not easy. It is never meant to be easy. It is born of a passion, and it is a commitment-a commitment to an idea, to principles, to fundamental human values.' Benazir Bhutto

\subsection{Background of the Study}

The life of Mohtarma Benazir Bhutto (henceforth referred to as Bhutto) is not one that needs any introduction. Born into a privileged family, she had to take on the responsibility of not only running her party after the death of her father, Zulfikar Ali Bhutto but also faced number of other challenges that would have balked many a person. Twice coming to power as Prime Minister of Pakistan, she has the honour of being the first Muslim woman to have achieved that position. Her untimely death on December 27, 2007

Naheed Malbari is currently doing her PhD in Social Sciences at SZABIST, naheed_mal@hotmail.com Dr. Javaid Laghari is Chairman Higher Education Commission (HEC) Pakistan, jlaghari@hec.gov.pk 
shocked the world, to say the least. Numerous articles were published in magazines and newspapers across the globe.

The plethora of such tributes can fill books. Yet if one assesses the very same, one realizes that most speak of her unique leadership abilities that allowed her to not only come to power twice but also to try for the third time which cost her, her very life. Thus the study of leadership and assessing her qualities is of interest to many.

\subsection{Research problem}

- To ascertain the fact that Bhutto can be regarded as a transformational leader, following questions are raised and answered:

- $\quad$ To what extent did the mass media's portrayal after her assassination reaffirm the fact that Bhutto had transformational leadership qualities?

- $\quad$ To what extent did charisma play an important role in Bhutto's leadership?

- To what extent has the media portrayed the four factors of transformational leadership applicable to Bhutto?

\section{$1.2 \quad$ Research Objectives}

In this paper, the researcher wishes to explore the concept of Transformational Leadership and its application to Bhutto's achievements in the light of articles written after her assassination.

- $\quad$ To see the extent to which the concept of transformational leadership as an important ideal is applicable for strong leadership.

- $\quad$ To denote which aspects of transformational leadership were more prevalent in the articles used for the study

\subsection{Significance and Scope of the Study}

The content used is limited to the articles written after her death by non-Pakistanis in the print media abroad and in Pakistan. Besides these, material is also taken from two books published after her assassination edited by Laghari (2008) 'Reflections on Benazir Bhutto' and the other by Halepota (2008) 'Benazir Bhutto-Political Thinker and Diplomat.' As Halepota's book deals with a plethora of articles, only the sections of selected articles in the National and International Press have been used. The reason for choosing nonnationals for understanding Bhutto's leadership is to give an unbiased view, where the sentiments of both her proponents and antagonists would hopefully not exist. Selected referencing from Bhutto's own writings and other references from transformational leadership in general have also been used in this study.

As transformational leadership includes multiple aspects only four aspects given outlined by Bass (1985); Bass et al. (2003) and Waldman, Javidan and Varella, (2004) have 
been analyzed. A limitation of this study, which needs to be mentioned here, is that not all the articles, which run into thousands, can be studied due to the time constraint of this study. One needs to remember that Bhutto's complete life is not one that can be done in a single independent study or over a limited time period, but analysis of her leadership capabilities can run into decades over tens of books and articles.

\subsection{Research Methodology}

Any research methodology fuses two aspects, namely, the theory that a researcher is going to follow and the method employed to conduct such a research.

\subsubsection{Theoretical Considerations}

This is a study of leadership and many theories of leadership are in existence. Theories whose base is on the leader's personal characteristics i.e. what leaders have called the Trait Theory, what leaders did or Behaviouristic Theory of leaders, leaders in different situations or Contingency Theory of leadership and lastly those which took the follower/leader concept into focus or Transformational leadership (Northhouse, 2007). Thus the theoretical base of this study is transformational leadership as it applies to Bhutto.

\subsubsection{Methodological Considerations}

Methodology is based on four major aspects, namely, research purpose, research methods, research style and research strategy. All four components are part of this research. The research purpose is a descriptive one and therefore a descriptive format is used. It also fuses a number of disciplines, namely leadership and the mass media. Secondly, the research method deals with documents which are secondary source of research. The style employed is based on one which deals with documentary research. Lastly the research strategy used is a fusion of two, namely content and narrative analysis.

Content analysis is used keeping in mind the theory of Transformational Leadership. Deemed historically to be a quantitative study and a neutral and objective way of gathering a specific kind of documentary data, the counting of specified items was deemed necessary (Berelson, 1952). This research follows Ray Pawson's (1995) thematic aspect of content analysis. This qualitative study uses human judgement.

Secondly, narrative analysis has been employed as a research strategy. According to Roberts in Bryman (2004), narrative analysis is a term that denotes a search that researchers employ to understand 'their lives and the world around them.' This research hopes to determine what the authors of the articles have said about Ms. Bhutto. A particular model, namely the thematic model of narrative analysis has been used, which coincides with content analysis strategy. It emphasizes on what is said rather than how it is said (Riessman, 2007). 
Such a documentary research may also be termed a historical one and has a number of merits. It may obtain knowledge of unexamined areas or re-examine questions. There can be a 'systematic and direct classification of data' and a systematic research can bring credibility and validity to the data (Marshall and Rossman, 2006). However, the weaknesses are the same as for all qualitative research, i.e. reliability can be questioned.

A review of related literature with regard to transformational leadership has been done with special emphasis on 'Leadership Quarterly' and other journals. Some internet sources are also utilized to see the original source of the edited articles that have been used in the study.

\section{Transformational leadership: An overview}

Although the term transformational leadership was coined by Downton (1973), the concept first emerged with the work of Burns (1978) which linked the role between leadership and followership. This new theory of leadership had intensive interest for two reasons. Western companies like AT and T, IBM, GM, ventured into transformations and in the 1970s and 1980s, the business world became very much dynamic, more competitive and less stable. Fast technological changes, great international competition, commercial deregulation, too much capacity in capital intensive industries, unsteadiness of oil cartels, demographic labour changes etc., are some of the factors which brought about such a state (Stoner and Freeman, 1992). Second, leadership's theoretic base rested on the trait theory, behaviouristic theory of leaders and contingency theory of leadership which did not take into consideration "untypical" qualities of leaders which required a new leadership concept.

Therefore the transformational theory of leadership gave forth a new dimension to leadership studies. Burns' (1978) concept distinguished between two types of leadership, namely transactional and transformational. Transactional refers to the exchanges between leaders and followers, whereas transformational is when the person engages with others and creates a connection which raises level of motivation in both the leader and the follower. Some of the examples of internationally known transformational leaders include Mahatma Ghandi, Nelson Mandela, and Martin Luther King. One question that comes to mind is about leaders like Hitler who also transformed society? Can they also be called Transformational leaders? When people transform society in negative ways and do not raise level of morality in others, they are described as pseudo-transformational leaders. They are self-consumed, power-oriented and exploitative with warped moral values.

Burns gave four categories in his typology: intellectual persons with vision e.g. Rousseau and Locke; reform persons who transform parts of society to realize moral principles e.g. Grey and Alexander; revolutionaries as Luther, Lenin, Mao and Fidel Castro and lastly heroic (charismatic) as Moses, Joan of Arc, Prophet Muhammad (pbuh) and John F. Kennedy. Though initially used by Weber (1947) to describe bureaucratic, charismatic and traditional leaders, House (1976) expanded and gave four phrases to define charismatic leadership showing them to be dominant and influential but also as confident 
with strong moral values. Later others gave similar but slightly differing conceptualizations of charisma (Conger and Kanungo,1985; Sashkin, 1988; Shamir, House and Arthur, 1993).

Bass $(1985,1990)$ introduced a Formal Transformational Leadership Theory with charisma, vision, intellectual stimulation and inspiration as the main components. From then on, a plethora of models came into being with leaders being led by values, vision, being social architects and modelling the way (Tichy and Devanna, 1986; Bennis and Nanus, 1985; Kouzes and Posner, 2002). Much research and studies were carried out as with Bass and Avolio (2000) giving the MLQ and others basing their studies on MLQ. Studies of transformational leadership stressed on acquisition integration (House and Aditiya, 1997; Yukl and Howell, 1999) and organizational change (Bass, Avolio, Jung and Berson,2003; Nemanich and Keller, 2007). Research has been undertaken in the context of organizations especially in areas of subordinate satisfaction with the leader and the perception of leaders effectiveness (Howell and Shamir,2005; Judge and Piccolo, 2004;).

Some research has also been done with transformational leadership being studied with variables such as subordinate job satisfaction (Judge and Bono, 2000; Podsakoff, MacKensie and Bommer, 1996) and recently combining subordinate job satisfaction and acquisition acceptance in major organisations( Nemanich and Keller, 2007). Other research takes into consideration leader/follower relationship dimensions with charisma being an important variable (Campbell, Ward Sonnenfeld and Agle, 2008). However the focus of this study has nothing to do with organizations but to do with political leadership which may transform the followers.

There has been some research done on political leadership but the focus of these studies have usually been on just one aspect, namely charisma (Bligh, Kohles and Meindl 2004 a and b; Emrich, Brower, Feldman and Garland, 2001; Mio, Riggio Levin and Reese, 2005; Seyranian and Bligh, 2007) and especially keeping in mind high profile leaders such as United States presidents (House, Spangler and Woycke, 1991). Most of such research has a quantitative analysis where the analysis may not overlook creative insights but also due to its frequent usage it is made to be more meaningful and most often words can be taken out of context. (Bligh et al., 2004b; Insch et al., 1997; Morris, 1994)

\section{Transformational leadership of Bhutto}

This research on Bhutto will be assessed on four parameters of idealized influence, inspirational motivation, intellectual stimulation and individualized consideration which have been summed up as stated earlier. Each quality will first be individually analyzed and then compared to what journalists and others have stated on Bhutto's behalf.

\subsection{Idealized influence}

According to this concept transformational leaders often 'serve as role models for their followers. The leaders are admired, respected and trusted... having extraordinary 
capabilities, persistence and determination' (Bass and Riggio, 2006). Not only this, but leadership theory should also stress on incidents where a leader has exerted exceptional influence on their followers so as to obtain favourable results (Bass, 1985; Mumford, 2006). This concept of idealized influence is based on leadership that has a future oriented vision and provides meaning and direction to a particular cause (Bass, 1990; Shamir, House and Arthur, 1993). Recent research also lays emphasis on ideological leadership where leaders seek followers who believe in the goals and value systems that lay emphasis on the prescriptive mental model being given (Mumford, 2006). A current research, which examines three areas of leadership has ideological factor as one of the main components (Mumford, Antes, Caughron and Friedrich, 2008). Thus, keeping all these factors in mind the assessment of Bhutto as having idealized influence on her followers has been undertaken.

Bhutto's idealized influence can be categorized into three areas in the articles reviewed. Firstly, the authors discussed her dedication to her country and her aspirations as a leader to bring democracy to Pakistan. Gordon Brown (2008) the Prime Minister of Britain mentions her dedication. Others like Hillen, (2008) calls it her "zeal for...democracy'; Gopal (2008) sees her as wanting to root out terrorism; Coates (2008) of her attracting strong party emotions; Ignatius, (2008) recalling her idealism and vision and her 'inner passion for change,' and Prasannarajan, (2008) speaking of her 'exceptionally singular' story and to combat odds of an 'under-developed civil society where power was nasty, brutal, tribal and masculine,' a transformational leader would be necessary.

Furthermore, most writers speak of her fortitude and her taking risks against all odds. Brown (2008) calls her a woman of 'immense courage and bravery.' Hitchens (2008) calls it 'extraordinary...courage'; Thapar (2008) remembers her words "fear is the last thought in my mind," and her 'steely confidence;' Gopal (2008) recalls her sheer determination and knowledge that 'she readily admitted that Washington's blessings were a kiss of death;' Baker (2008) and Ignatius (2008) too comment on similar facets with Hirsh (2008) stating that though she knew jammers were not working, in death she became the hero which she 'never quite became in life.'

Another aspect which comes to the forefront is that Bhutto challenged traditions and was a role model for many. Lamb (2008) recalls how Bhutto wore glass bangles instead of gold and refused the traditional trousseau to set an example. On the political front, Bhaumik (2008) states that she wanted lasting peace with India instead of the usual conflict. As a role model, Thapar (2008) comments on how she never revealed that her counterpart Rajiv Ghandi too had made promises on Saichen which he too was unable to keep but Bhutto never revealed the fact despite criticism. Tharoor (2008) recalls her capability in keeping the party together by her 'persona.'

\subsection{Inspirational motivation}

According to this concept, transformational leaders 'motivate and inspire those around them by providing meaning and challenge to their followers' work.' (Bass and Riggio, 2006) Such leaders envisage a future goal, a shared vision which they want their 
followers to share and achieve with them. Apart from this, such leaders portray great charisma which allows them to bind their followers to themselves and lead them towards social change. This concept of charismatic leadership is also not a new but a much researched one. It is one of the way in which one can understand an aspect of effective leadership (Hughes, Ginnett and Curphy, 2003). As previously stated, the concept was initially used by Weber (1947) to understand and describe the characteristics political, religious and military leaders. Later the concept was expanded by others to give different conceptualization of charismatic leadership (House, 1977; Sashkin,1988; Shamir, House and Arthur 1993) and also became a part of transformational leadership in the theories of Bass and Avolio (1994).

Concept of charismatic leadership, which becomes a part of the motivational factor, has been studied. The concept of visionary charismatic leadership is very important, especially in times of crises as indicated in the study of Hunt, Boal and Dodge (1999). Two further aspects came to the forefront with on the one hand followers prefer leaders who portray charisma in conditions of crises (Pillai and Meindl, 1998) and followers attributing 'self sacrificial behaviour' of the leader under crisis conditions who were more likely to portray charisma (Halverson, Holladay, Kazama, and Quinoes, 2004). Such studies portray the fact that stressful conditions do affect both the leader and the follower in how they are inspired and view charisma. Another aspect of inspirational motivation is to deal with how such leader appeal to their followers. Emotions of people are appealed to and self worth is enhanced (Emrich, Brower, Feldman and Garland, 2001; House, Spangler and Woyke, 1991)

Bhutto's inspirational motivation can be analyzed into two areas, namely to motivate and empower others on a shared vision and her charisma. On the count of motivating others, many authors have given glowing tributes. Gordon Brown (2008) calls it 'a part of her legacy that women are empowered...' and would use her for future role models; Miliband (2008) and Schofield (2008) describe her commitment towards democracy as a motivating factor; Lamb (2008) recalls her spouse Zardari calling his wife the 'queen bee' whose workers needed her alive to continue their struggle; Gopal (2008) realizes that Bhutto did inspire a generation both in life and in death to struggle for democracy; Prasannarajan (2008) states that despite threats she never shrank from her responsibility, took up challenges and made personal sacrifices for her vision and that such motivation is rarely seen; Baker (2008) sees the signing of the charter of democracy between two political opponents namely Bhutto and Sharif as a factor to restore decent politics and joining hands on a common denominator; Chua-Eoan (2008) despite critical comments concedes that Bhutto both in life and death drew millions.

Next many authors concede to the fact that Bhutto had a charismatic personality. Lamb (2008) calls Bhutto 'Boadicea riding her chariot' when seeing her on the bus and also recalls Zardari calling her a 'superwoman'; Hillen (20080 quoting Wallace calls Bhutto 'bigger than a human being-she was a spirit over there'; Hitchens (2008) speaks of her 'mass appeal... against the siren calls of the fundamentalists'; Thomas (2008) recalls Bhutto as a 'star power,' and compares her allure to that of Elizabeth Taylor; Usher (2008) states that Bhutto's charisma made her political opponent Sharif call her his 
sister; Perlez and Burnett (2008) use words like 'charismatic' and 'striking', 'saviour' for millions of Pakistan's 'poor and disenfranchised'; Lewis (2008) gives a preview of her hard life and knows that a movie on her played by Meryl Streep for him would be a fitting end; Witte and Wax (2008) remember her party official Babar Awan calling her 'beautiful that day, in all the ways that a woman like her -bright energetic bursting with ideas and hope-could look beautiful.' Such charisma denotes why Bhutto had many staunch supporters.

\subsection{Intellectual stimulation}

Such transformational leaders stimulate their followers' efforts to be innovative and creative. Followers are encouraged to try out new ideas and such ideas are viewed in the light that a better solution to the problem may be realized. Followers are not criticized if their ideas are in anyway different from the ideas of the leader (Bass and Riggio, 2006). This concept has been explained differently and in various contexts. Some call it as a quality of a pragmatic leader. Such a leader does require their workers to unite and work for common goals (Mumford and Van Doorn, 2001). In a recent study Mumford et al (2008) realized that for the emergence of pragmatic leaders there has to be a minimum level of group cohesion. Apart from this, the same study also indicated that pragmatic leaders 'may seek to minimize political conflict due to the detrimental effects of intense conflict on the effective application of complex problem solving skills.' This factor is an important aspect of intellectual stimulation as such a quality can harness together differing view points and opinions even from the opposition.

Emotionally intelligent leadership is also an attribute of great leadership (Goleman, 1995). Practical intelligence and the need to modify any environment to suit the situation is also what transformational leaders need to do. Another aspect of intellectual stimulation can be assessed through the lens of 'aesthetic perception.' This recent qualitative study by Ladkin (2008), embodies and focuses on 'leading beautifully' and will lead to a different direction for leadership studies in the future. Followers can get stimulated in a wide variety of ways. The power to arouse ones followers intellectually can have lasting effects. An example of it would be Obama's books being published before the election campaigns.

Thus any analysis of Bhutto on her intellectual stimulation can be done on three fronts. Firstly, she used innovative ways to solve age old problems which was what her followers learnt from her. Thapar's (2008) article portrays her as someone who 'forged a link with L.K. Advani,' and thought of a different solution to the age old Kashmir problem, of 'soft borders, free trade and even, perhaps unrealistically, a joint parliament for the two halves of Kashmir'; Baker (2008) states that Bhutto encouraged and stimulated an opponent Sharif and herself to follow a new path in politics which portrayed her intellectual calibre as a transforming leader.

Additionally, her own books and writings and speeches intellectually stimulated not only her followers but all those around the world. Though the premise of the paper is not a study on her latest book 'Reconciliation', yet what many have written after her death 
and publishing of her book can show us, her transformational leadership qualities. By writing on a controversial issue, Bhutto was in many ways forging a pathway towards understanding the dichotomy that exists between East/West ideologies and how by a process of thought can one reach better solutions to age old problems. Siegel (2008), who collaborated with her on the book, speaks about her criticism for both extremism and dictatorship and the fact that one aids the other i.e. 'nurtured and fuelled by it.' Siegel spoke about the ideology of the book i.e. the 'internal crisis within Islam and that 'between Islam and the West.' He goes on to state that, for her very principles, she took on the wrath of many that resulted in her assassination.

Her fiery speeches stimulated many to follow her. Witte and Wax (2008) recall how she, as a leader, stimulated her followers in her last message before her assassination. In the park where thousands cheered she told '"wake up, my brothers!"' Her fiery speech of the 'grave dangers' facing her nation would require their followership. Halliday (2008) recounts that meeting Bhutto was an experience one could never forget. Her intellect and other qualities made her stand apart and compare her at times over 'played grandiloquence' to other South Asian elite.

\subsection{Individualized Consideration}

Once again, transformational leaders pay attention to 'followers needs for achievement and growth by acting as a coach and mentor.' New ways and opportunities of learning are evolved and individual desires and needs are seen to. The individual is regarded as a 'whole person rather than just an employee,' and the task of the leader is to develop the followers. (Bass and Riggio, 2006)

This aspect is seen under two areas. The first one is her immense kindness to others and her concern for them. Schofield (2008) speaks of her 33 year association with Bhutto and states that 'as a friend, she was kind and generous.' Barak (2008) recalls his own incident of injury and her kindness to him which must have endeared her to people the world over. In a similar manner, Thapar (2008) too remembers Bhutto giving regular calls when his own wife was seriously ill. Lamb (2008) too speaks of Bhutto's hand written will which she had written prior to her death as how to dispose of her belongings with details of how even her shoes and clothes should be distributed among her employees.

Also Bhutto understood the concept of politics in Pakistan and the need to mix and move with them and be near them. Also when cautioned by Thapar (2008) of terrorist attacks in 2007 , she categorically stated that she could not fight a terrorist by portraying fear and that if people are willing to risk their lives for her then 'politicians must be ready to face that situation first.' Lamb (2008) speaks of Bhutto being out among her people and 'pressing the flesh,' and being accessible. Therefore Bhutto always tends to 'stand on top of the bus or out of the sunroof of armoured cars.' This was not something new. Hitchens (2008) remembers that in 1988 on the last night of her first election campaign, she took the car herself went into the slums of Karachi, climbed the roof of her jeep and tried to be as close as possible to them. In another instance, according to Baker 
(2008) a vegetable vendor Naeem wad reminiscing as to who would take care of the likes of him. Pakistan's poor were her staunchest supporters. She was thus an icon for the powerless and downtrodden.

\section{Conclusion}

One needs to remember that these articles written by non-Pakistanis-days or at the most a couple of weeks after Bhutto's assassination-were spontaneous reactions to her death. When doing such a research, one needs to keep in mind that these articles were not written specifically about her as a leader, but simply as what people thought of her in the aftermath of her death. These facts can be taken in two ways. Some may state that the sympathy lay with Bhutto as she was so tragically assassinated and thus any articles written after her death would therefore endeavour to shed light on her in a favourable way. On the other hand, these articles can be viewed differently with the fact that when people write on such a topic so soon after her demise, true sentiments are revealed as there is very little time to reflect or couch ones words as stress often reveals the truth.

The premise of the study was a simple one i.e. to see if any of the authors had portrayed her as a transformational leader in the period immediately after her death. Also the fact that only foreign non-Pakistani writers were taken, was deliberately done so that element of bias would substantially be reduced. The study is based primarily on four aspects of transformational leadership. Other viewpoints discussed of transformational leadership have not been assessed if they are in anyway different from the four above.

Most of the articles were anywhere between 550 to 1500 words long, though some may have been slightly longer. It would have been very difficult for the authors to have tried to analyze her life and achievements in such a short article. Each author was not necessarily analyzing her life but was only spontaneously reflecting on their first hand interaction with her. So on the above counts, one can conclude the study in two differing ways. The question here arises that did all the articles deal with her as a transformational leader on all the four criteria i.e. idealized influence, inspirational motivation, intellectual stimulation and individualized consideration or did the articles depict only a few aspects of her as a transformational leader.

All the articles did deal with one or two aspects of her as a transformational leader. Much evidence is available on the first two aspects of transformational leadership, namely idealized influence and inspirational motivation.

In the former i.e. idealized influence, the articles did prove that without doubt Bhutto did influence her followers on this parameter. Bhutto has often been regarded as someone who possessed these very same qualities. Thus these western writers have oft quoted her as being a woman who challenged many of the prevailing norms of women not taking the centre stage in a developing country like Pakistan. She was one who was able to look ahead into the future and envisage a modern forward moving Pakistan. Such leaders endear themselves to the public, especially those who want to 
move on and make the best of what they have.

Numerous examples were available in the articles regarding Bhutto's inspirational motivation. The fact that she did have a different vision from the usual military leadership in the country and did take personal risks which led to her untimely death are all testimony to the fact that she did inspire masses to what she envisaged for her country Pakistan. Therefore one can conclude in retrospect that as a charismatic leader Bhutto was able to initiate once again a mass movement towards restoration of democracy.

Little substance was available on her intellectual stimulation in the articles but that is understandable as such information would be more readily available with party workers and others she was directly in contact with. However, an important aspect of her leadership abilities that should be mentioned is that the articles did state that, apart from ideological and motivational/charismatic qualities, in recent years, Bhutto had matured into several aspects of a pragmatic leader with her 'Reconciliation' book that tried to bridge the east/west dichotomy as well as with taking along her political opponent Sharif into signing the Charter of Democracy so as to minimize political conflict. Also the study is limited to these two editors who incorporated international and national articles in the aftermath of her death. Her book 'Reconciliation' and the reviews in Halepota's book by the press abroad, have not been included which might have provided insightful other details on this aspect. This analysis could be a matter of a separate study on the subject.

Also though information has been available on the aspect of individualized consideration, this too has not been as detailed as the first two aspects. One factor that came to the forefront is that Bhutto was immensely kind to many, both friend and opponent. Also she understood the need of the Pakistani people to mix and 'press the flesh' was her undoing. Many people comment that she took unnecessary risks but that had always been her way and thus she could not envisage doing anything different.

The dearth of research, especially on transformational leadership on our political leaders, is unfortunate. The lessons one can learn from analyzing a leader in the qualitative context may give an impetus to others in coming forward and doing such research. The public in Pakistan is politically conscious yet only journalistic analysis has been undertaken so far. One hopes this research will minimize this lack to some extent.

\section{Limitations of this Study and Scope for future research}

One needs to stress that a complete leadership study on Bhutto has not been done at this point in time. This is a study only on a limited aspect of leadership. The study of any leader or leadership cannot be done with a stroke of a pen or limited to two edited version of articles written after her death or within a limited time frame as this research calls for. A careful assessment even just keeping in view the fact that mass media requires many months of analysis. Also qualitative study via thematic analysis has its own limitations as many may say that words and meanings can be interpreted differently by different researchers and a more analytical method of formal content analysis would 
have been preferable. Yet, as with any research, formal content analysis, has its own share of problems, as discussed earlier. However a research based on all aspects or even two aspects of content analysis in the time given would not have done full justice to the study. Another limitation is that as a woman, a popular leader and a former head of Pakistan, the death of Bhutto caused emotions to run very high and many an article expressed a strong criticism against the Musharraf Government and regime.

Bhutto can be studied in detail keeping any of the other detailed aspects and theories of leadership in mind. Also the same content can be taken and used for the other forms of content analysis, namely formal content analysis, textual and audience analysis. Apart from this, her book 'Reconciliation' can be studied keeping in view the above perspective, especially regarding intellectual stimulation or with a differing format. 


\section{References}

Baker Aryn, 2008, 'Making a martyr of Bhutto', in Zulfiqar Halepota (Ed.) Benazir Bhutto: Political Thinker and Diplomat, Sindhica Academy, Karachi.

Barak Daphane., (2008), 'How Benazir let her hair down', in Laghari Dr, J.,(ed.) Reflections on Benazir Bhutto, SZABIST, Karachi.

Bass, B. M. (1985) Leadership and Performance Beyond expectations, The Free Press, New York.

Bass, B. M. (1990) Bass and Stogdill's handbook of leadership: theory, research and managerial applications, Free Press, New York.

Bass B. M., and Avolio B. J., (1994), Improving organizational effectiveness through transformational leadership, Sage, thousand Oaks, CA.

Bass, B. M., Avolio B. J., Jung D., and Berson Y., (2003), 'Predicting unit performance by assessing transformational and transactional leadership', Journal of applied psychology, Vol. 88, pp. 207-218.

Bass B. M. and Riggio R. E., (2006), Transformational Leadership, Lawrence Erlbaum Publishers, London.

Bennis W. G. and Nanus B., (1985), Leaders: The strategy for taking charge, Harper and Row, New York.

Berelson, B., (1952) Content analysis in communication research, Free Press, Glencoe, IL.

Bhutto Benazir, (2008), Reconciliation: Islam, Democracy and the West, Simon and Schuster, London.

Bligh M. C., Kohles J. C., and Meindl J. R., (2004a), 'Charisma under crisis: Presidential leadership, rhetoric and media responses before and after 9/11', Leadership Quarterly, Vol. 15, pp. 211-239.

Bligh M. C., Kohles J. C., and Meindl J. R., (2004b), Charting the language of leadership: A methodological investigation of President Bush and the crisis of 9/11, Journal of Applied Psychology, Vol. 83, pp. 562-574.

Brown Gordon., (2008), Democracy must be Benazir's lasting memorial, in Laghari Dr, J., (ed.) Reflections on Benazir Bhutto, SZABIST, Karachi.

Burns J. M., (1978) Leadership, Harper and Row, New York. 
Burns J. M., (2003), Transforming Leadership, Grove Press, New York. Bryman Alan, (2004), Social Research Methods, Oxford University Press, Oxford.

Campbell S. M., Ward A. J., Sonnenfeld J. A., and Agle B. R., (2008), Relational ties that bind: leader-follower relationship dimensions and charismatic attribution, Leadership Quarterly, Vol. 19, pp. 556-568.

Chua-Eoan Howard, (2008), Benazir Bhutto, in Zulfiqar Halepota (ed.) Benazir Bhutto: Political Thinker and Diplomat, Sindhica Academy, Karachi.

Coates Nicholas, (2008), Pakistan loses a fighter for democracy, in Laghari Dr, J.,(ed.) Reflections on Benazir Bhutto, SZABIST, Karachi.

Conger J. A., and Kanungo R. N., (1998), Charismatic leadership in organizations, Sage Pub., Thousand Oaks, CA.

Downtown, J. V., (1973), Rebel Leadership: Commitment and charisma in the revolutionary process, Free Press, New York.

Emrich C. G., Brower H. H., Feldman J. M. and Garland H., (2001), Images in words: Presidential rhetoric, charisma and greatness, administrative Science quarterly, Vol. 46, pp. 527-557.

Goleman Daniel, (1995), Emotional Intelligence, Bantam, New York.

Gopal Neena., (2008), World has lost a leader, in Laghari Dr, J.,(ed.) Reflections on Benazir Bhutto, SZABIST, Karachi.

Halliday Fred, (2008), The Assassin's Age: Pakistan in the World, in Zulfiqar Halepota (ed.) Benazir Bhutto: Political Thinker and Diplomat, Sindhica Academy, Karachi.

Halverson S. E., Holladay C. C., Kazma S. M., and Quinines M. A., (2004), Self-sacrificial behaviour in crises situations: The competing roles of behavioural and situational factors, Leadership quarterly, Vol. 15, pp. 211-240.

Hillen Michelle, (2008), Arkansas friend calls Bhutto a tireless spirit, in Laghari Dr, J.,(ed.) Reflections on Benazir Bhutto, SZABIST, Karachi.

Hirsh Michael, (2008), A Hero for Democracy, in Zulfiqar Halepota (ed.) Benazir Bhutto: Political Thinker and Diplomat, Sindhica Academy, Karachi.

Hitchens Christopher., (2008), Daughter of Destiny, in Laghari Dr, J.,(ed.) Reflections on Benazir Bhutto, SZABIST, Karachi.

House R. J., (1977), 'A 1976 theory of charismatic leadership', in, Hunt J. G. and Larson 
L. L. (ed.), Leadership: The cutting edge, Southern Illinois University Press, Carbondale, IL.

House R. J., Spangler W. D., Woyke J., (1991), 'Personailty and charisma in the U.S. presidency: A psychological theory of leader effectiveness', Administrative Science Quarterly, Vol. 36, pp. 364-396.

House R. J., and Aditya, R. N. (1997), The Social Scientific Study of Leadership: Quo Vadis? Journal of management, Vol. 23, pp. 409-473.

Howell J. M., and Shamir B., (2005), 'The role of followers in the charismatic leadership process: Relationships and their consequences', Academy of management review, Vol. 30, pp. 96-112.

Hughes R. L., Ginnett R. C. and Curphy G. J., Leadership: enhancing the lessons of experience, Irwin McGraw-Hill, New York.

Hunt J. G., Boal K. B., Dodge G. E. (1999), 'The effects of visionary and crises responsive charisma on followers: An experimental examination of two kinds of charismatic leadership', Leadership quarterly, Vol. 10, pp. 423-448.

Ignatius David, (2008), The legacy of Benazir, in Laghari Dr, J.,(ed.) Reflections on Benazir Bhutto, SZABIST, Karachi.

Insch G.S., Moore J.E., and Murphy L.D., (1997), 'Content analysis in leadership research: Examples, procedures and suggestions for future use', Leadership Quarterly, Vol. 8, pp. 1-25.

Judge T. A., and Bono J. E., (2000), 'Five factor model of personality and transformational leadership', Journal of Applied psychology, Vol. 85, pp. 751-765.

Judge T. A., and Piccolo R. F., (2004), 'Transformational and Transactional leadership: A meta-analytic test of their relative validity', Journal of Applied psychology, Vol. 89, pp. 755-768.

Kouzes J. M. and Posner B. Z., (1987), The leadership challenge: How to get extraordinary things done in organizations, Jossey-Bass, San Fransisco.

Ladkin D., (2008), 'Leading beautifully: How mastery, congruence and purpose create the aesthetic of embodied leadership practice', Leadership Quarterly, Vol. 19, pp. 3141.

Laghari Dr. Javaid (ed.) (2008), Reflections on Benazir Bhutto, SZABIST, Karachi. Lamb Christina., (2008), 'My life with Benazir,' in Laghari Dr J., (ed.), Reflections on Benazir Bhutto, SZBIST, Karachi.

Journal of Independent Studies and Research - MSSE

Volume $8 \quad$ Number 1 January 2010 217 
Lamb Christina., (2008), 'I begged my bibi to avoid murder rally', in Zulfiqar Halepota (ed.) Benazir Bhutto: Political Thinker and Diplomat, Sindhica Academy, Karachi.

Lewis Roger, (2008), 'Benazir Bhutto's last message to us', in Zulfiqar Halepota (ed.) Benazir Bhutto: Political Thinker and Diplomat, Sindhica Academy, Karachi.

Marshall Catherine and Rossman Gretchen B., (2006), Designing Qualitative Research, Sage Publications, London.

Miliband David., (2008), 'Benazir Bhutto', in Laghari Dr,J.,(ed.) Reflections on Benazir Bhutto, SZABIST, Karachi.

Mio J. S., Riggio, R. E., Levin S. and Reese R., (2005), 'Presidential leadership and charisma: the effects of metaphor', Leadership Quaarterly, Vol. 16, pp. 287-294.

Morris R., (1994), 'Computerized content analysis in management research', Journal of Management, Vol. 20, pp. 903-931.

Mumford M. D., (2006), Pathways to outstanding leadership: A comparative analysis of charismatic, ideological and pragmatic leaders, Erlbaum, Mahwah, NJ.

Mumford M. D., Antes A. L., Caughron J. J., Friedrich T. L., (2008), 'Charismatic, ideological, and pragmatic leadership: Multi-level influences on emergence and performance', Leadership Quarterly Vol. 19, pp. 144-160.

Mumford M. D., and Van Dorn J. R., (2001), 'The leadership of pragmatism: Reconsidering Franklin in the age of charisma', Leadership Quarterly, Vol. 12, pp. 274-309.

Nemanich A. L., Keller R. T., (2007), 'Transformational Leadership in an acquisition: A field study of employees', Leadership Quarterly, Vol. 18, pp. 49-68.

Northouse Peter G., (2007), Leadership Theory and Practice, Sage Publications Inc, India.

Pawson Ray, (1995), Methods of content/document/media analysis in Haralambos M, (ed.) Developments in Sociology, Vol. 11, Causeway Press, Ormskirk.

Perlez J., and Burnett, (2008), 'Benazir Bhutto lived in the eye of Pakistan's storm', in Zulfiqar Halepota (ed.) Benazir Bhutto: political thinker and diplomat, Sindhica Academy, Karachi.

Pillai R., and Meindl J. R., (1998), 'Context and charisma: A 'meso' level examination of the relationship of organic structure, collectivism, and crisis to charismatic leadership', Journal of Management, Vol. 24, pp. 643-671.

Podsakoff P. M. Mac Kensie S. B. and Bommer M., (1996), 'Transformational leader

Journal of Independent Studies and Research - MSSE

Volume $8 \quad$ Number 1

January $2010 \mid 218$ 
behaviours ad substitutes for leadership as determinants of employee satisfaction, commitment, trust and organizational citizenship behaviors', Journal of Management, Vol. 22, pp. 259-298.

Prasannarajan S., (2008), 'Martyr of democracy', in Laghari Dr, J.,(ed.) Reflections on Benazir Bhutto, SZABIST, Karachi.

Riessman Dr. Catherine Kohler, (2008), Narrative methods for the Human Sciences, Sage publications Inc, United Kingdom.

Sashkin M., (1988), The visionary leader, in J.A. Conger and R.N.Kanungo (ed.), Charismatic Leadership: The elusive factor in organizational effectiveness, JosseyBass, San Francisco.

Schofield Victoria; (2008), 'Benazir Bhutto: A great and brave friend', in Laghari Dr J., (ed.), Reflections on Benazir Bhutto, SZABIST, Karachi.

Seyranian V., and Bligh M. C., (2008), 'Presidential charismatic Leadership: Exploring the rhetoric of social change', Leadership Quarterly, Vol. 19, pp. 54-76.

Shamir, B., House R. J., and Arthur M. B., (1993), 'The motivational effects of charismatic leadership: A self concept based theory', Organizational Science, Vol. 4, pp. 577-594.

Siegal Mark A., (2008), Benazir's legacy, in Zulfiqar Halepota (ed.) Benazir Bhutto: Political Thinker and Diplomat, Sindhica Academy, Karachi.

Stoner, J. A. R, and Freeman, R. E., (1992), Management, Prentice-Hall of India, New Delhi.

Thapar Karan., (2008), 'My Friend Benazir', in Laghari Dr, J.,(ed.) Reflections on Benazir Bhutto, SZABIST, Karachi.

Thapar Karan., (2008), 'A warm understanding and caring person', in Laghari Dr, J., (ed.) Reflections on Benazir Bhutto, SZABIST, Karachi.

Tharoor K., (2008), 'Benazir murdered: What next?,' in Zulfiqar Halepota (Ed) Benazir Bhutto: Political Thinker and Diplomat, Sindhica Academy, Karachi.

Tichy N. and Devanna M. A., (1986), The transformational leadership, Wiley, New York.

Thomas Cal, (2008), 'A patriot's tragic death', in Laghari Dr, J.,(ed.) Reflections on Benazir Bhutto, SZABIST, Karachi.

Waldman,D., Javidan, M., and Varella, P. (2004), 'Charismatic leadership at the strategic level: A new application of upper echelons theory', Leadership Quarterly, Vol. 15, 355380.

Journal of Independent Studies and Research - MSSE

Volume 8

Number 1

January 2010 219 
Usher Graham, (2008), 'Benazir Bhutto a death foretold', in Zulfiqar Halepota (ed.) Benazir Bhutto: political thinker and diplomat, Sindhica Academy, Karachi.

Weber M., (1947), The theory of social and economic organization, (trans. T. Parson) Free Press, New York.

Witt G., and Wax E., (2008), 'Bhutto's last day in keeping with her driven life', in Zulfiqar Halepota (ed.) Benazir Bhutto: Political Thinker and Diplomat, Sindhica Academy, Karachi.

Yukl G., and Howell J. M., (1999), 'Organizational and contextual influences on the emergence and effectiveness of charismatic leadership', Leadership Quarterly, Vol. 10, pp. 257-283. 